\title{
Dreaming in Fire and Working in Clay: The Problem of Translating Ideas into Words in Arthur Machen's The Great God Pan
}

\begin{abstract}
The present article explores Arthur Machen's (1863-1947) influential work The Great God Pan (1894) in terms of the discrepancy between Machen's original aim in writing the novella, which was expressing the sublime feelings he experienced when he beheld the valley of Usk in his native Wales - and the result, a horror tale where Pan seems to embody the ultimate evil. Taking into account the original idea, as well as the final rendition problematises the idea of a sinister Pan, making him more ambiguous. First, the final version of "The Great God Pan" is analysed in terms of its Decadent features, as well as its effect on the reader, features that placed it in the horror genre. Subsequently, a contrasting way of reading is offered that considers the circumstances that gave rise to the novella. From this reading, Pan emerges as a transcendent spirit of Nature rather than an embodiment of evil.
\end{abstract}

Key words

Arthur Machen; Decadence; The Great God Pan; horror; abject; Nature

\section{Arthur Machen: The Decadent Apostle of Wonder ${ }^{1}$}

Arthur Machen (1863-1947) became famous after he published his influential novella "The Great God Pan" (1894). The book caused an outrage when it first appeared in the Keynotes Series published by John Lane's Bodley Head Press, becoming "one of the nineties' most common targets for antidecadence criticism" (Ferguson 2002: 474) and, at the same time, "one of the series' most successful 
titles" (MacLeod 2006: 120), with the scandal fuelling demand. In Machen's words, "There was a storm - in a doll's teacup" (1923: 96). Since Machen was one of the authors associated with Decadence, one can only assume that such a reaction was positively received by the author. After all, Decadence is often associated with a desire to shock and provoke, in a relentless fight against Mrs. Grundy. And, indeed, Machen was "fond of citing the horrified reactions of readers and reviewers alike" (Joshi 1990: 21). He quotes several negative reviews in Things Near and Far (1923), the second volume of his autobiography (Machen 1923: 96-99), and he even published a collection of negative reviews of his work, which is entitled Precious Balms (1924). Being one of the "modern masters" of supernatural horror (Lovecraft 2012: 81), Machen created a sinister Pan, who - in the eyes of the characters of the story, if not necessarily in those of the author himself - represented the ultimate evil. Accordingly, Patricia Merivale in her study Pan the Goat-God: His Myth in Modern Times (1969) included Machen within the chapter entitled "The Sinister Pan in Prose Fiction." However, when one examines Machen's original intentions along with the final execution of the story, Pan becomes more awful in the original sense of word: inspiring feelings of awe and wonder, rather than horror. Indeed, at the beginning of Machen's writing "The Great God Pan" stands a desire to express the sublime beauty of natural scenery in his native Gwent. What lies at the end, however, is a horror story, a cautionary tale of what might happen when the laws of Nature are tampered with. Instead of expressing the transcendent beauty of Nature, Pan came to represent the ultimate evil.

At the heart of this discrepancy is Machen's constant struggle with giving his ideas shape in writing, which he describes in Far Off Things (1922), the first volume of his autobiography: "[O]ne of the first agonies of the learner in letters is the discovery of the horrid gulf that yawns between the conception and the execution. ... that gulf between the idea as it glows warm and radiant in the author's heart, and its cold and faulty realisation in words is an early nightmare, and a late one, too" (2013: 100-101). Machen further describes how, as a budding author, he had some hope of overcoming this, but he admits defeat in the end: "But now, with riper understanding, he perceives, as he did not perceive in the days of his youth, the depth of the gulf between the idea and the word, between the emotion that thrilled him to his very heart and soul, and the sorry page of print into which that emotion stands translated. He dreamed in fire; he has worked in clay" (101). Machen portrayed this struggle in his semi-autobiographical novel (and his masterpiece) The Hill of Dreams (1907), where Lucian, Machen's alter ego, experiences the same difficulty with translating his ideas into words as a writer. In fact, when describing his feelings about his rejected manuscript, Lucian uses the same metaphors as Machen does in Far Off Things: "He knew how weak it all was compared with his own conceptions; he had seen an enchanted city, awful, glorious, with flame smitten about its battlements, like the cities of the Sangraal, and he had moulded his copy in such poor clay as came to his hand; yet, in spite of the gulf that yawned between the idea and the work, he knew as he read that the 
thing accomplished was very far from a failure" (Machen 2006: 102). Despite his alter ego's acknowledgement that the work was "very far from a failure," Machen was a very self-conscious writer, highly critical of his work.

As "The Great God Pan" was written at the beginning of Machen's literary career, the gulf between the idea and the execution seems to be especially wide. In Far Off Things, he describes his original aim behind writing the story as "an endeavour to pass on the vague, indefinable sense of awe and mystery and terror that I had received" upon seeing "the valley of Usk ... on one of those strange days of summer when the sky is at once grey and luminous ... and there is no breath of wind, and every leaf is still" (2013: 19-20). In this respect, Machen's strategy approaches that of Symbolist writers, the aim of the story being to serve as a symbol for evoking the same feelings in the reader as Machen himself experienced while contemplating the valley. However, he regarded the result as a failure: "I translated awe, at worst awfulness, into evil; again, I say, one dreams in fire and works in clay" (123). This implies that the story was supposed to evoke sublime feelings of awe and wonder, but instead evoked horror due to Machen's inability to successfully translate his ideas into words.

An important factor informing Machen's works is his religious and philosophical views, which were shaped by his family. His father was a vicar, having come from a long line of clergymen. Machen himself was Anglo-Catholic and "firmly convinced that the orthodox belief was the right, the only belief"2 (Gawsworth 2013: 229). His philosophy is quite succinctly described by Joshi:

The sole goal of Machen's philosophy is to restore the sense of wonder and mystery into our perception of the world; everything that tended to foster such goal -mysticism, occultism, Catholicism, symbolism - was to be encouraged, and everything that hindered it - Protestantism (criticized as appealing too much to the rational intellect), science, rationalism, realism was to be furiously combated. (1990: 16)

While, for Machen, everything that mattered in the world was indescribable, "ineffable" (Machen 2013: 155), at the same time to express the ineffable was his ultimate literary ambition. And if it could not be done directly, Machen reached for symbolism to achieve his aim. Quoting Machen, Joshi describes what exactly the author meant by a symbol: "We live in a world of symbols; of sensible perishable things which both veil and reveal spiritual and living and eternal realities.' The only true 'realism,' therefore, is symbolism, because the symbol is the reality, or at least as close to the ineffable reality as we can get" (1990: 16, original emphasis). The veil is one of Machen's most important metaphors. He uses it repeatedly to express his Neoplatonic view of the universe, in which the perishable material world is just a reflection, a shadow, of the ineffable reality: "I define realism as the depicting of eternal, inner realities - the "things that really are' of Plato - as opposed to the description of transitory, external surfaces" (Machen 2013: 42). 
Not surprisingly perhaps, Machen despised materialism, which is reflected in one of the key notions of his work - ecstasy - meaning the sense of "a withdrawal from the common life" (Machen 2011: 111). In Machen's view, this is the key ingredient of good writing: "[A]ll fine literature is the work of ecstasy and the inspirer of ecstasy" (Machen 1923: 57). Joshi explained this notion further as "a penetration through the ordinariness of daily existence to the spiritual realities beyond" (1990: 27). Machen's work in which this is most clearly conveyed is the short novel "A Fragment of Life" (1906), which, being centred around the notion of ecstasy, "captures the essence of Machen's world view" (Joshi 1990: 27). "A Fragment of Life" tells the story of Edward and Mary Darnell, a young respectable (and repressed) married couple, who receive a gift of one hundred pounds from Mary's aunt and spend most of their time trying to decide how to spend the money most prudently. Indeed, the first part of the story consists of extensive discussions of the prices, quality and usefulness of the things they are considering purchasing. However, their mundane existence is gradually transformed by Edward's awakening spirituality as he starts exploring his Welsh heritage. The following passage from Things Near and Far succinctly expresses "what is the real heart of the story" (Joshi 1990: 27) and Machen's life philosophy: "And it is utterly true that he who cannot find wonder, mystery, awe, the sense of a new world and an undiscovered realm in the places by the Gray's Inn Road will never find those secrets elsewhere, not in the heart of Africa, not in the fabled hidden cities of Tibet... All the wonders lie within a stone's throw of King's Cross Station" (Machen 1923: 56). Ecstasy is, then, not about the place where one is, but rather about one's perspective and state of mind. It can be achieved in rural Wales, as well as in urban London, although the former is much more conducive to it. The notion of ecstasy is also at the core of "The Great God Pan," as seeing the god represents penetrating the world of shadows and breaking into the eternal world of Forms. Dr. Raymond, the scientist who conducts the fatal experiment, says that the material world - the mountains, hills, fields and stars - "all these are but dreams and shadows; the shadows that hide the real world from our eyes. There is a real world, but it is ... beyond a veil ... and the ancients knew what lifting the veil means. They called it seeing the god Pan" (Machen 2006: 10, ellipses added). Dr. Raymond is a typically Gothic Frankenstein-like scientist, who tries to access forbidden knowledge regardless of the consequences. Indeed, when Clarke, a friend of Raymond's who is about to witness the experiment, expresses his concern about Mary's safety, the misogynistic Raymond replies: "I think her life is mine, to use as I see fit" (12). Raymond is far from a positive character, reflecting perhaps Machen's profoundly negative view of science. What is more, the outcome of the story suggests that Machen disapproved of the attempt to access the world of Forms in this way - by dint of the scientific method.

Despite being an orthodox Anglo-Catholic, Machen was an "iconoclast" and "delighted in shocking the élite" (MacLeod 2006: 121). Like other Decadents, he despised materialism and "loathed business in all its aspects" (Gawsworth 2013: 73), particularly industrialism as it led to ruining the countryside he loved 
so much. Embracing the doctrine of art for art's sake, he detested "the notion that literature should be "practical' or utilitarian" (191). In his works, he often criticises Victorian hypocrisy (particularly in The Hill of Dreams). ${ }^{3}$ Moreover, being frustrated with having to rewrite his works to satisfy Mrs. Grundy, in his preface to Fantastic Tales, he compared Victorians to a generation "not of vipers, but of crocodiles, the which beast is pronounced by ancient authors to be exceeding hypocritical, and ferocious also" (Machen qtd. in Gawsworth 2013: 95). His characters are "dilettantes" who, "in privileging the esoteric, ... valorize the antibourgeois and anti-professional values of the Decadents who aimed to escape their [middle]class origins" (MacLeod 2006: 122). Lucian, the protagonist of The Hill of Dreams, is a typical example of a life-negating Decadent hero in pursuit of the esoteric, "falling in love more and more with useless reading and unlikely knowledge" (Machen 2006: 79). Moreover, Machen's affiliation with Decadence also shows in his literary tastes: one of the books he loved was De Quincey's Confessions of an English Opium-Eater (Machen 2013: 41); he was "impressed by Wilde's The Picture of Dorian Gray" (Gawsworth 2013: 100) and, most importantly, he counts Swinburne among his most significant literary influences. In Far Off Things, Machen describes the effect Swinburne's Songs Before Sunrise (1871) had on him as "cataclysmic"4 (2013: 92):

First there was the literary manner of the book, which to me was wholly strange and new and wonderful, and then there was the tremendous boldness of it all, the denial of everything that I had been brought up to believe most sure and sacred; the book was positively strewn with the fragments of shattered altars and the torn limbs of kings and priests. (2013: 92)

A statement like this might seem to be hard to reconcile with Machen's orthodox Anglo-Catholicism. Actually, this was far from unusual among Decadent writers, many of whom converted to Catholicism. In fact, Marion Thain identifies this relationship as one of the Decadent paradoxes. She lists the examples of Joris-Karl Huysmans, Paul Verlaine and Arthur Rimbaud in French literature, and Oscar Wilde, Lionel Johnson, Ernest Dowson, Aubrey Beardsley, Lord Alfred Douglas, John Gray, André Raffalovich, Frederick Rolfe, and 'Michael Field' (Katharine Bradley and Edith Cooper) in British Decadence (2007: 230). Apart from the obvious aesthetic appeal that Decadent writers found in the ornate Catholic ritual (as opposed to the more austere Protestantism), what they also shared with this religion was a marginal position. Indeed, in this period, "puritan anti-Catholicism was particularly strong" and "Catholicism and Decadent literature were often condemned in much the same terms" (230). Machen's case was then only different in the fact that he was already Anglo-Catholic before he started writing Decadent works. 


\section{"The Great God Pan" as a Source of Horror}

Having described Machen's original idea behind "The Great God Pan," I will now analyse the result in terms of its Decadent features and the reactions it triggered. The novella made Machen famous, or rather infamous at first, sparking outrage and making the critics question its author's sanity (Gawsworth 2013: 125-126). It tells the story of an experiment gone wrong. Dr. Raymond, an expert in "transcendental medicine" (Machen 2006: 9), operates on the brain of Mary, a girl he has rescued "from the gutter" (12), activating a group of nerve cells whose function has not been accounted for. The aim of the experiment is to "level utterly the solid wall of sense" (12) which prevents people from accessing the spiritual world behind - the world of eternal ideas hidden behind the perishable material symbols. In short, the aim is for Mary to "see the god Pan" (12) or the world as it really is. He is successful in activating those brain cells, but the operation has devastating consequences for the girl, who, having seen Pan, goes mad. However, she gives birth to a girl, an offspring of Pan, who becomes a femme fatale, causing a series of men to commit mysterious suicides.

The unfortunate experiment is witnessed by Dr. Raymond's friend Clarke, a detective-like character with a typically Decadent curiosity and interest in the arcane. Clarke wants to uphold his image as a respectable gentleman, but, at the same time, is struggling with his keen interest in the occult: "In his sober moments he thought of the unusual and the eccentric with undisguised aversion, and yet, deep in his heart, there was a wide-eyed inquisitiveness with respect to all the more recondite and esoteric elements in the nature of men" (Machen 2006: 17). This interest resembles addiction, which, throughout the story, Clarke keeps battling: "For more than a week he had succeeded in keeping away from the 'Memoirs,' and he cherished hopes of a complete self-reformation" (32). Contrasting with the more serious addiction to alcohol and other drugs typically associated with the image of Decadents, the passage has a somewhat comic tone, being probably a parody of the Victorian desire for self-development and earnestness. ${ }^{6}$ Another detective-like character with a similarly Decadent disposition and inquisitive nature is Villiers, who enjoys rambling through the city "in search of those mysterious incidents and persons in with which the streets of London teem in every quarter and at every hour" (24). As a proper Decadent dilettante, "Villiers prided himself as a practised explorer of such obscure mazes and byways of London life, and in this unprofitable pursuit he displayed an assiduity which was worthy of more serious employment" (24). Moreover, he has "a constitutional liking for useless information" (55). In its uselessness, Villier's hobby is then very similar to Clarke's, which is collecting manuscripts with all sorts of bizarre incidents and "documents on the most morbid subjects" (18). And it is in one of these that Clarke learns, years after Raymond's experiment, of two curious incidents centred around Helen Vaughan, an orphan who was sent by his guardian to "a village on the borders of Wales, a place of some importance in the time of the Roman occupation" (19). The guardian turns out to be Dr. Raymond, and 
Helen is the daughter of Mary and Pan. She is sent away because of her disturbing encounters with her father, as Raymond explains in a letter to Clarke: "When [the child] was scarcely five years old I surprised it, not once or twice but several times with a playmate, you may guess of what kind. It was for me a constant, an incarnate horror" (66).

It is the nature of these encounters that inspires dread in all who witness them. The first incident happens "on one of the very hottest days in this summer," when Helen goes for her regular walk in the woods, taking "the old Roman Road" (20). She is witnessed by a little boy, as she is "playing on the grass with a "strange naked man" (20). The boy is "dreadfully frightened" (20) and runs to his father. For several weeks, he is plagued by recurring nightmares from which he awakens with a cry "The man in the wood! father! father!" (21). The problems gradually recede until the boy accompanies his father on his way to work at the house of a gentleman where he sees a statue which frightens him so much he loses consciousness and is found "lying senseless on the floor, his face contorted with terror" (21). After he comes round, he suffers from "violent hysteria" (21). On leaving the house after being medicated, he sees the statue again and cries "The man in the wood" (21); this second shock leaves him mentally ill permanently. The reason the statue, "evidently of the Roman period" (21), frightens him so much is the fact that it depicts "a faun or a satyr" (22) and it is described by one of the witnesses as "a vivid presentment of intense evil" (22). In the second incident, Helen is accompanied on her walk to the woods by her friend Rachel, whom her mother later finds in her room deeply traumatised, undoubtedly by witnessing Helen frolicking with Pan, and perhaps even participating. After this incident, Helen disappears from the village, but later appears in London as a woman who brings utter ruin to Villier's friend Herbert, "corrupt[ing] him body and soul" (26). She is also responsible for the demise of a man found in front of Herberts' house, who "blank died of fright, of sheer, awful terror" (30). Finally, Helen is discovered to be Mrs Beaumont, whose utter depravity compels five London gentlemen to commit suicide, after each had spent a night at her house.

It is never said explicitly what is so shocking about Helen's behaviour that such disastrous consequences await the people involved - it is only vaguely described as "awful, unspeakable events" (Machen 2006: 23) - but it can be assumed that the horrors concerned illicit sexual behaviour, which must have been particularly outrageous for an orthodox Catholic like Machen. Joshi describes the story as "a frenzied expression of horror over illicit sex" and notes that readers did not fail to grasp the source of horror in the story, to which their reaction corresponds: "Machen's early readers ... reacted with the shock and disgust to be expected of late Victorian audiences. ... But Machen's own reaction, implicit in the story, seems even more exaggerated than that of his contemporary readers: aberrant sex becomes, for Machen, a sort of 'sin against Nature' - something that threatens the very fabric of the cosmos" (1990: 21). Here Machen's conservative (and possibly repressed) ${ }^{7}$ nature comes to light. However, he seems to have been both terrified and fascinated by the idea of transgressive sex, 
be it homosexual intercourse, unconventional sexual practices or even incest, since Helen was Pan's daughter. Quoting Lovecraft, Joshi explains why Machen felt that way: "People whose minds are - like Machen's - steeped in the orthodox myths of religion, naturally find a poignant fascination in the conception of things which religion brands with outlawry and horror" (1990: 21). To a more liberal-minded reader, the vague descriptions sometimes seem ridiculous and exaggerated to the point of being absurd as, for instance, in Herbert's description of Helen's shocking depravity:

I can say you may have heard the talk of the vilest, but I tell you you can have no conception of what I know, no, not in your most fantastic, hideous dreams can you have imaged forth the faintest shadow of what I have heard - and seen. Yes, seen. I have seen the incredible, such horrors that even I myself sometimes stop in the middle of the street, and ask whether it is possible for a man to behold such things and live. (Machen 2006: 26)

In this novella, which, not surprisingly, gave rise to parodies, ${ }^{8}$ Machen employed a strategy used by many Decadent writers for good reason: had the work been more explicit in its depictions of these vague horrors, it could not have been published in the prurient Victorian society. Kirsten MacLeod explains that "The gaps and silences make an otherwise unpublishable story publishable" (2006: 127). Even so, it caused considerable controversy. Another reason to employ this strategy was its aesthetic effect. Commenting on The Picture of Dorian Gray, Wilde explained that the purpose of the vagueness and indeterminacy allows every reader to fill the gaps with what is - for them - the most dreadful abomination: "Each man sees his own sins in Dorian Gray. What Dorian Gray's sins are no one knows. He who finds them has brought them" (Wilde qtd. in MacLeod 2006: 125-126). This required a greater deal of imagination on the part of the reader, but the effect was personalising the sins and horrors that constitute the central part of the story. What is more, this strategy had "the added bonus of exposing the prurience of his detractors" (MacLeod 2006: 126).

What exactly happens in these incidents is never said, but the basis of the horrors is easily deduced. At the very centre is Helen, part human, part god, or simply, a devil, as the Latin sentence in Clarke's "Memoirs" conveys: "Et diabolus incarnatus est. Et homo factus est" (Machen 2006: 23) meaning "And a devil was made incarnate. And a human being was produced." Pan, Helen's progenitor, has often been identified with the devil, and this novella is no exception, especially when he is the source of all the evil happening there. Helen's Graeco-Roman heritage is clearly visible in her features; she was born in England, but she has a "clear, olive skin and almost Italian appearance" (22). The Graeco-Roman culture was particularly appealing for Decadent writers with homosexual inclinations. It is not surprising, then, that Machen chose a lustful Graeco-Roman god to represent - what were in the eyes of many Victorians - the evils of sexual transgression. Elaine Showalter explains why transgression in general was so dis- 
concerting to many Victorians at the end of the century, when the strict divisions between genders, sexualities, and races began to crumble:

In periods of cultural insecurity, when there are fears of regression and degeneration, the longing for strict border controls around the definition of gender, as well as race, class, and nationality, becomes especially intense. If the different races can be kept in their places, if the various classes can be held in their proper districts of the city, and if men and women can be fixed in their separate spheres, many hope, apocalypse can be prevented and we can preserve a comforting sense of identity and permanence in the face of that relentless specter of millennial change. (1992: 4)

It is also significant that the source of terror in the story is a woman. This seems to reflect "the late-Victorian fascination with an atavistically aggressive female" (Kaye 2007: 57), with Helen joining the company of Oscar Wilde's Salome, H. Rider Haggard's Ayesha and Bram Stoker's vampirical women. In fact, Nicholas Ruddick argues that Machen's "The Great God Pan" "anticipates Dracula's theme of the dangers of unrestrained female sexuality" (2007: 204). Actually, Bernheimer points out that the fin de siècle aggressive female is at the origin of Freud's theory of sexuality: "Freud's vision of female sexual development ... is a vision inherited from the decadent imagination of the fin de siecle: woman is castrated and castrating, the male is her prey, she wants to make his phallus her own" (178). The fin de siècle femme fatales were in turn probably inspired, to some degree, by the rise of the New Woman and the anxiety this triggered: "Men feared emasculation or supersession by the rising generation of well-educated, free-thinking, assertive New Women, but their fears were often modified into ambivalence by erotic excitement" (Ruddick 2007: 192). Showalter further explains the unsettling effect of women, pointing out that "Women have traditionally been perceived as figures of disorder," and that "Women's social and cultural marginality seems to place them on the borderlines of the symbolic order, both the 'frontier between men and chaos,' and dangerously part of chaos itself' (1992: 8).

What helps to clarify the disturbing impression Helen makes is the concept of the uncanny, ranging from Sigmund Freud's essay Das Unheimliche (1919) to Julia Kristeva's notion of the abjection. What produces the uncanny effect in Helen is the paradox of her being both stunningly beautiful and utterly revolting, which is very difficult to process. Indeed, she is described by people who have seen her as "at once the most beautiful woman and the most repulsive they had ever set eyes on" (Machen 2006: 31); and, according to Herbert, she spoke "in her beautiful voice ... of things which even now I would not dare whisper in blackest night, though I stood in the midst of a wilderness" (26). Again, the surface is beautiful, but the core abominable. To put it short, she is a monster in a human body. The beauty in her face comes from Mary, her mother; the repulsiveness, from an inner corruption she has inherited from Pan. In her outward beauty and inward corruption, which shows in her facial expression, Helen evokes a similar disparity 
between Dorian Gray's physical beauty and inner corruption, which is only given expression in Basil's painting. Machen was "a good deal impressed by" The Picture of Dorian Gray (qtd. in Gawsworth 2013: 100), so this similarity is probably not coincidental. The names are symbolic, too: her mother's name is suggestive of Virgin Mary, whose innocence was - in being seduced by Pan - corrupted by the sinful Graeco-Roman god. Kostas Boyiopoulos supports this connection, noting that, like Virgin Mary, Helen's mother is "dressed all in white" which symbolises her "youthful innocence," and "her blind compliance to the scientist" is comparable to Virgin Mary's "absolute faith in God" (2010: 364). Helen inherits her mother's beauty, but her identity is much closer to her Graeco-Roman father, her name evoking Helen of Troy, the daughter of Zeus and Leda. After all, seeing Zeus had the same fatal consequences as seeing Pan. What further supports Helen Vaughan's link with Helen of Troy is her stunning beauty. The latter appears as the embodiment of physical beauty in Thomas Nashe's play Summer's Last Will and Testament, specifically in the song "Adieu, farewell, earth's bliss" about the transience of life on earth, which resonates with Machen's Neoplatonism and foregrounding of the spiritual over the material:

Beauty is but a flowre,

Which wrinckles will deuoure,

Brightnesse falls from the ayre,

Queenes haue died yong and faire,

Dust hath closde Helens eye.

I am sick, I must dye:

Lord, haue mercy on vs. (1905: 283)

Helen is an apt symbol here, being, according to the myth, the most beautiful woman in the world. Her ultimate beauty makes the contrast with Helen Vaughan's utmost inner corruption even more striking. Boyiopoulos, however, sees Helen as an embodiment of "Lilith, the Judaic figure and archetype of feminine horror" (2010: 369). He makes a very good case for this comparison when he points out "Lilith's familial bond with the Devil and the incestuous, sexual relationship with him" (369) and the fact that, like Helen, she "kills the men she is entangled with by means of asphyxiation" (371).

Helen defies the neat categories Victorians cherished so much in being a shapeshifter. This starts at a symbolic level with her unstable identity. In the course of the story, she assumes three identities (apart from her original one): Mrs. Herbert (after her marriage), Mrs. Raymond, and Mrs. Beaumont. But, at the end of the story, when Clarke and Villiers make her commit suicide, she becomes a shapeshifter at a much more fundamental level. The strange course of her death is recorded in Dr. Matheson's manuscript:

"... I was then privileged or accursed, I dare not say which, to see that which was on the bed, lying there black like ink, transformed before my eyes. The 
skin, and the flesh, and the muscles, and the bones, and the firm structure of the human body that I had thought to be unchangeable, and permanent as adamant, began to melt and dissolve. ... there was some internal force, of which I knew nothing, that caused dissolution and change.

"Here too was all the work by which man has been made repeated before my eyes. I saw the form waver from sex to sex, dividing itself from itself, and then again reunited. Then I saw the body descend to the beasts whence it ascended, and that which was on the heights go down to the depths, even to the abyss of all being. The principle of life, which makes organism, always remained, while the outward form changed." (2006: 61-62, ellipses added)

Helen's death is another moment of abjection, both in Machen's story and in Nashe's poem, where the embodiment of physical beauty is subject to decay. Kristeva describes the abject as "the jettisoned object," something "radically excluded" that draws one "toward the place where meaning collapses" (1982: 2). Seeing the abject is accompanied by feelings of deep revulsion, which function as a defence mechanism: "Loathing an item of food, a piece of filth, waste, or dung. The spasms and vomiting that protect me. The repugnance, the retching that thrusts me to the side and turns me away from defilement, sewage, and muck" (2). It makes one avert one's gaze and get away to avoid contamination, as in Kristeva's most famous example of abjection - beholding a corpse: "The corpse, seen without God and outside of science, is the utmost of abjection. It is death infecting life" (4). The witnesses of Helen's death experience abjection not only because, at the end, they see her corpse; her death is much more disturbing because it represents the ultimate breaking down of boundaries, not only those between life and death, but also those between human and animal. Her dying, transforming body shows them the human form and what may become of it (at least in the scope of the fictional story). Helen ceases to be a subject, becoming abject by being expelled from the symbolic order. The abject is "what disturbs identity, system, order. What does not respect borders, positions, rules. The in-between, the ambiguous, the composite" (4), and that is certainly Helen's case. Not fitting into the symbolic order, the abject is something we cannot grasp because it does not match the established concepts, as in Kristeva's examples of "a friend who stabs you" or "the criminal with a good conscience" (4), or, as in Machen's story, a beautiful woman who is a monster. Helen's transgressing the boundaries between the species is another contamination from which the abject is supposed to protect us: "By way of abjection, primitive societies have marked out a precise area of their culture in order to remove it from the threatening world of animals or animalism, which were imagined as representatives of sex and murder" (12-13). Helen transcends this boundary both in her identity and her behaviour.

And so does Pan. At one moment, the jelly-like substance which is left after Helen disappears assumes the shape of Pan: 
I watched, and at last saw nothing but a substance like to jelly. Then the ladder was ascended again ... [here the MS. is illegible] for one instant I saw a Form, shaped in dimness before me, which I will not further describe. But the symbol of this form may be seen in ancient sculptures, and in paintings which survived beneath the lava, too foul to be spoken of ... as a horrible and unspeakable shape, neither man nor beast, was changed into human form, there came finally death. (Machen 2006: 62, original ellipses)

Just like Helen, Pan is seen as abject. What is disturbing about him is not only his sexual frolics; it is mainly the fact that he is "neither man nor beast," transcending the boundary between human and animal. In this respect, the story reflects the fears that followed from Charles Darwin's theory of evolution, which wrought havoc upon the strict division between species. Commenting on Jekyll and Hyde and H. Rider Haggard's She, Ruddick points out that these works "participate in the cultural absorption of the Darwinian insight into the proximity of the human and animal realms" (2007: 193). And the same applies for "The Great God Pan." The omissions in the manuscript show that the witnesses experienced considerable difficulty putting what they had seen into words; after all, standing outside the symbolic order, the abject is impossible to translate into language. Navarette further explains the characters' speechlessness: "Trapped in their pre-Freudian nightmare worlds, such tongue-tied characters ... see to express an irreferable something that triggers an unnameable response .... Their encounter with the unheimlich coincides with a momentary surcease of expressiveness, in a stifling of speech signaling an abrupt reversion to hereditary memories, latent instincts, perhaps instinctive loathing" (1998: 198). According to Navarette, the reaction of the characters provides a clue for the reader of such works:

In their unveiling not merely of a decompositive body occupying an otherwise unthinkable plane of existence, but also of those other bodies that are degraded by what is itself degraded, many works of fin de siècle horror explore precisely this form of abjection, which seeks to elicit a physical response in the reader - a visceral shudder or a sense of physical aversion brought on by the propinquity of something lacking "cleanliness or health," something degenerative, "radically separate, loathsome," often something unnameable. The propriety of such a response is never in doubt because in all such stories the hero or narrator reacts in precisely the same fashion - setting an example, as it were, for the reader to follow. (196)

Linda Dowling points out that the inability of the characters to express what they experience in words is a particularly recurrent motif in Decadent literature, identifying it as "the unutterability topos, the familiar convention that asserts the total inadequacy of language to express what is meant" (2014: 161). In "The Great God Pan," this topos "operates thematically to associate written language itself with the literary 'unspeakable' phenomena of primeval physical horror" (162). 
In Lacanian terms, these traumatic moments of "primeval physical horror" that Helen as the abject induces would be described as the eruption of the Real, threatening one's material existence. Like the abject, the Real cannot be expressed by language because it stands outside the Symbolic, the realm of signifiers.

On the whole, "The Great God Pan" is a notable example of fin de siècle Gothic, taking place not in an ancient castle or magnificent mountains, but in contemporary London, and dealing no more with evil monks or hereditary curses, but with science: "If the city is now the primary Gothic landscape, the primary figure at the heart of most Victorian fin de siècle texts is the scientist" (Byron 2012: 188). What is more, Helen is not the only example of the abject in this genre; Byron points out that the abject is what "the transgressive monsters of Victorian fin de siècle Gothic" share, reflecting the fears about an unstable identity (195) (resulting, among other things, from Darwin's discoveries). This is connected with another shift in the genre of Gothic: the source of terror is no longer external, for "The threat ... seems to reside within human nature itself, a nature potentially deviant and destructive when freed from the fetters of social and ethical taboos and codes of behavior, taboos, and codes that, the text ultimately suggests, are necessary for the stability of both society and the individual" (191). And Pan, especially the animal-half of him, is an appropriate figure for expressing the dangers of transgressive behaviour. Accordingly, Byron argues that "the trauma represented by Helen has less to do with supernatural forces than with a simple liberation from repression" (191).

There is one more aspect of the story that is connected with the topic of science and that makes the story Decadent (although in a more subtle way). Christine Ferguson, continuing the trend of positive reappraisal of Decadence, argues that the self-destruction of the protagonists at the end of many Decadent texts does not represent their failure, but rather is the result of "triumphant experimentalism" (2002: 471), of challenging the limits of knowledge:

When we recognize the decadent script as positivistic bildungsroman in which the subject develops by mastering approved forms of knowledge and then challenging the order of meaning in which subjectivity is articulated, it is no longer possible to view the suicides that frequently mark its conclusions as clumsy failures. Rather, such conclusions logically culminate an attempt to master, dissect, and transcend conventional modes of epistemology. (471-472)

She analyses "The Great God Pan" in terms of "its intense enactment of the epistemiphilic plot" (474), a pursuit of knowledge for its own sake, which challenges Victorian utilitarianism. Dr. Raymond is an embodiment of a progressive, ruthless Victorian scientist bound to "unleash the primordial truth of existence from its last hiding place" (475), not caring about the price to be paid for this, which, as it turns out, is first his subject's sanity and then her life. Pan's offspring Helen transcends all limits and challenges the idea of a stable 
self by being at once a shape-shifting and a radically destabilising force: "She aims to induce the same type of ontological collapse that accompanied her birth in all those who look on her" (475). This reaches its climax at the moment of her death: "Vaughan's ultimate refutation of the imperative to be semantically stable and socially useful - to, above all else, mean something - comes, ironically, when she confronts the greatest of all limitations placed on the subject: death" (475). Ferguson offers a good explanation for an otherwise weak part of the story, the moment when Clarke forces Helen to commit suicide: "Vaughan's relentless transformation makes a mockery of the finitude associated with death; indeed, such a mockery is arguably the main reason for her compliance with Clarke's laughably feeble threats. (After all, why would the child of an immortal pagan deity, able to drive people mad on sight, fear a man with a rope?)" (475). What is more, Helen's destabilizing influence does not cease with her death, for "the surviving witnesses remain deeply traumatized, unable to return to and trust the familiar conventions of Victorian morality and meaning" (474). This profoundly unsettling effect resulting from the challenge to the prevailing conventions is one of the reasons why the novella was recognised as Decadent by the critics (474).

\section{Pan as the Sublime Spirit of Nature}

Having examined the terrifying aspect of Pan, which makes the story a piece of horror literature, I will now turn my attention to the less obvious aspect of Pan in the story and that is his connection to Nature, where Pan appears as a more benevolent force. This link is by no means unusual; Pan has often been seen as a spirit of Nature, especially in Romanticism and Transcendentalism. What is more, Machen's original motive behind writing "The Great God Pan" indicates his close connection to Nature, which played an important role in his works and which was forged by the place in which he grew up: Caerleon-on-Usk, Monmouthshire, in south east Wales, which he describes (using its Welsh name) as "that wonderful magic Gwent" (2013: 19). In his autobiography, he expresses the deep attachment he felt to his birthplace: "I shall always esteem it as the greatest piece of fortune that has fallen to me, that I was born in that noble, fallen Caerleon-on-Usk, in the heart of Gwent" (8). His favourite occupation was solitary strolls in the hills and forests around the rectory of Llanddewy where he lived, and he even attributes his interest in writing and his literary achievements to his birthplace: "The older I grow the more firmly am I convinced that anything which I may have accomplished in literature is due to the fact that when my eyes were first opened in earliest childhood they had before them the vision of an enchanted land" (8). The beautiful countryside of Gwent, which for Machen was imbued with wonder and mystery, is probably also from where his interest in mysticism stems. In his imagination, the region was populated by fairies, and he often compares Gwent to a "fairyland" (21), although Machen's fairies are far 
from the charming winged creatures one knows from fairy tales. Caerleon was not only rich in folklore, but also a place steeped in the legends of King Arthur and his knights: the town is said to be "the legendary capital of their realm" (Gawsworth 2013: 3). The second moment ${ }^{8}$ to which he attributes his desire to write is his walk "in the woods of Hereford," the town where he studied: "Being caught in the rain with the birds singing about him and the mystic atmosphere of the tale of Owain from the Mabinogion' clouding his senses, he says it 'left on my mind a very strong and singular impression which, when the desire to write literature came upon me, I yearned to put into words"' (Gawsworth 2013: 25). It was then Machen's enchantment by the Welsh countryside coupled with his interest in Celtic legends that fuelled his desire to write.

Not surprisingly, then, Machen's love of Nature and his Celtic heritage had a strong bearing on his writing. His metaphors and comparisons are often based on Nature, making his writing lyrical (like Forrest Reid's, another writer who employed the Pan motif in his work). What follows is an example of this lyricism from "The Great God Pan": "Clarke watched changes fleeting over that face as the changes of the hills when the summer clouds float across the sun" (2006: 15). But there are many more in "The Three Impostors" and The Hill of Dreams. Machen ascribed his lyrical disposition, the desire to reflect the beauty of Nature in the beauty of the language, to his Celtic origins: in Far Off Things, he says that "Celtdom," as opposed to "Anglo-Saxondom" is more sensitive in perceiving "the music of words and the relation of that music to the world" (2013: 87). When he was trying to learn the pronunciation of a particular Welsh phrase, he was told to "speak it so that it makes a sound like the wind about the mountains" (87). Accordingly, to express the sounds of Nature in the sound of words became the aim of both Machen and Lucian in The Hill of Dreams: "He had tried to sing in words the music that the brook sang, and the sound of the October wind rustling through the brown bracken on the hill ... To win the secret of words, to make a phrase that would murmur of summer and the bee, to summon the wind into a sentence, to conjure the odour of the night into the surge and fall and harmony of a line" (2006: 213-214). Actually, the aim of Lucian's work is very similar Machen's idea behind "The Great God Pan": "[I]t was a pious attempt to translate into English prose the form and mystery of the domed hills, the magic of occult valleys, the sound of the red swollen brook swirling through leafless woods" (Machen 2006: 101). Indeed, Nature is intrinsically connected with Lucian's writing. As he is reading his manuscript, he remembers exactly what the weather was like when he was writing the particular passages:

This had been painfully excogitated while the snowstorm whirled about the lawn and filled the lanes, this was of the summer night, this of the harvest moon rising like a fire from the tithebarn on the hill. ... he had thought out the sentences one evening, while he leaned on the foot-bridge and watched the brook swim across the road. Every word smelt of the meadowsweet that grew thick upon the banks; now, as he recalled the cadence and the phrase 
that had seemed so charming, he saw again the ferns beneath the vaulted roots of the beech, and the green light of the glowworm in the hedge (213).

However, both Machen and Lucian believed to have failed. At the end of the story, Lucian admits his defeat:

He remembered that in some fantastic book he had seen a bar or two of music, and, beneath, the inscription that here was the musical expression of Westminster Abbey. His boyish effort seemed hardly less ambitious, and he no longer believed that language could present the melody and the awe and the loveliness of the earth. He had long known that he, at all events, would have to be content with a far approach, with a few broken notes that might suggest, perhaps, the magistral everlasting song of the hill and the streams. (214)

Machen also often contrasts the urban and rural landscape in his writing, clearly preferring the latter. This is particularly apparent in "A Fragment of Life" and The Hill of Dreams.

Considering how close a relationship Machen had to Nature and what a significant role it plays in his writing, it is surprising that the association between Pan and Nature in "The Great God Pan" is not particularly strong. After all, the Pan of the finished novella is a negative force, giving rise to an incarnate evil in the shape of his diabolical offspring. It has already been said that Machen considered the result a failure. However, there are traces of his original intention at the beginning of the story, with Nature playing an important role. The odour Clarke smells during Raymond's experiment brings to his mind a memory of a sweltering summer day "fifteen years ago, that he had spent roaming through the woods and meadows near his old home" (Machen 2006: 13). The odour brings about a change in Clarke's consciousness, making the present blurred and the memory vivid. Actually, the following depiction of Clarke's memory could have been inspired by the sight of the valley of Usk in the summer that gave rise to the story:

[I]t was his last look at the fields and woods he had known since he was a child, and now it all stood out in brilliant light, as a picture, before him. Above all there came to his nostrils the scent of summer, the smell of flowers mingled, and the odour of the woods, of cool shaded places, deep in the green depths, drawn forth by the sun's heat; and the scent of the good earth, lying as it were with arms stretched forth, and smiling lips, overpowered all. (14)

The description of the beauties of the English countryside gradually yields to a more Mediterranean region evoked by "a vine ... droop[ing] with purple grapes" and "a wild olive-tree [which] stood out against the dark shadows of the ilex" (14), anticipating the appearance of Pan, whose arrival is marked by "an infinite 
silence [which] seemed to fall on all things, and the wood was hushed"10 (14). It is then when Clarke, in his altered consciousness, has a vision of Pan: "[F]or a moment of time he stood face to face there with a presence, that was neither man nor beast, neither living nor dead, but all things mingled, the form of all things but devoid of all form" (14). The drug that Raymond uses in the experiment and that induces this vision in Clarke is then similar in effect as the operation itself. However, since Clarke only seems to be dreaming of Pan and does not encounter him in all his awe, it does not drive him mad; his presence is safely veiled by the dream. It is, then, here where Machen manages to approach his original aim in writing the story: here Pan truly inspires feelings of awe, rather than horror, and appears as a transcendent spirit of Nature. It is this aspect which makes Machen's Pan ambiguous rather than purely evil. Being "all things mingled" and a deity representing Nature, he necessarily comprises both good and bad.

\section{Revisiting the Awful God Pan}

Although "The Great God Pan" made Arthur Machen famous and influenced not only writers employing the Pan motif in their work, but also those writing in the horror genre, the author himself considered it a failure. Actually, when one examines Machen's view of literature, it turns out that the failure was inevitable: "I think ... that all that really matters and really exists is ineffable; that both the world without us - the tree and the brook and the hill - and the world within us do perpetually and necessarily transcend all our powers of utterance, whether to ourselves or to others" (2013: 155). At the core of his failure, then, is the fact that the topics that are - in his view - worth writing about are at the same time inexpressible, outside the realm of language.

Nevertheless, Machen did not give up. Dreaming in fire, yet working in clay, he created a horror story where Pan and Pan-like figures represent, what is according to the account of the characters in the story, "an incarnate horror" (Machen 2006: 66), an evil that is beyond anything they can imagine. Instead of communicating to the reader the ineffable, sublime feeling Machen experienced upon beholding the valley in Gwent, Pan, and his offspring Helen, came to symbolize something completely different, yet equally inexpressible, the abject - that which stands outside the Symbolic, and, thus, cannot be translated into language.

Nevertheless, Machen's original aim in writing the story and his dissatisfaction with the result problematises the categorisation of the story as a piece of horror literature, making Pan more ambiguous. The Graeco-Roman god was not supposed to be the villain or the monster of the piece, but rather a symbol of the transcendent beauty of Nature. What is more, Machen had been "fascinated from youth by the Roman ruins of Isca Silurum near his birthplace" (Joshi 1990: 12), so the GraecoRoman culture was not something he found repulsive or of which he disapproved.

But even the idea of Pan in the story could not be entirely negative. In embodying the world of Forms, the god approaches the Orphic Pan, which is described 
by Merivale as the spirit of "universal Nature" or " soul" of the World" (1969: 9). The only difference is that he is not only the spirit of Nature, but is also nature in the sense of "the essence of all things." Claiming that Pan is evil would imply that the world of Forms is inherently evil. In fact, the origin of Machen's Pan can then be traced to Swinburne, the Decadent writer who influenced him so much and whose originality in his treatment of Pan, according to Merivale, lies "in his combination of the notion of terror with that of a universal nature spirit, in the manner suggested by Carlyle and Robert Louis Stevenson in prose. These two had developed the Romantic 'universal' Pan by adding the possibilities of malevolence and terror, for 'all' nature, they said, must inevitably include terror as well as beauty and joy" (98). In Machen's version of Pan, terror meant transgressive sex, which, although evil in Machen's view, would later be represented more positively in the writing of other authors in this Pan tradition, writers such as Victor Benjamin Neuburg, Forrest Reid, and E. M. Forster.

\section{Notes}

Arthur Machen: Apostle of Wonder is the title of Machen's biography by Mark Valentine.

The fervour of Machen's belief and his religious conservatism is apparent from his description of the Protestant Reformation as "the most hideous blasphemy, the greatest woe, the most monstrous horror that has fallen upon the hapless race of mortals since the foundation of the world" (qtd. in Gawsworth 2013: 215).

3 A salient example of Machen's satiric critique of Victorian hypocrisy is the following passage from The Hill of Dreams:

"... That wretched young man passed me this afternoon; he was quite intoxicated."

"How very sad," said Mr. Dixon. "A little port, my dear?"

"Thank you, Merivale, I will have another glass of sherry. Dr. Burrows is always scolding me and saying I must take something to keep up my energy, and this sherry is so weak."

The Dixons were not teetotallers. They regretted it deeply, and blamed the doctor, who "insisted on some stimulant." However, there was some consolation in trying to convert the parish to total abstinence, or, as they curiously called it, temperance. (Machen 2006: 135)

4 In Machen's usage, the word "cataclysmic" has positive connotations. Talking about a doctrine of a friend of his, he explains that "we are all much bettered by an occasional earthquake, moral, mental or spiritual. He says that volcanoes which suddenly burst out from under our feet are the finest tonics in the world, that violent thunderstorms, cloud-bursts, and tornadoes clear our mental skies" (Machen 2013: 92).

5 For more information on this topic, see Ellis Hanson's book Decadence and Catholicism (1998) and David Hilliard's article "UnEnglish and Unmanly: Anglo-Catholicism and Homosexuality" (1982), which both explore the affinity between Anglo-Catholicism and homosexually inclined Decadent writers.

6 Machen shared Clarke's interests and approved of them. When Clarke comes up with a rational explanation of Villiers' feeling of sickness after visiting Herbert's house, he "secretly congratulat[es] himself on having successfully kept up the character of advocate of the commonplace" (Machen 2006: 36). And, for Machen, an advocate of wonder, the commonplace was something he despised. This transpires from his critique of the education system in "The Fragment of Life": "Darnell had received what is called a sound commercial education, and would therefore have found very great difficulty in putting into articulate speech any thought that was worth thinking; but he grew certain on these mornings that the 'common sense' which he had always heard exalted as man's supremest faculty was, in all 
probability, the smallest and least-considered item in the equipment of an ant of average intelligence" (Machen 2011: 204).

7 The theme of repression also underlies the relationship of the married couple in "The Fragment of Life," a novella with autobiographical features.

8 "The Great God Pan" inspired two parodies published a year later: Arthur Compton-Rickett's "A Yellow Creeper" (1895) and Arthur Sykes's "The Great Pan-Demon: An Unspeakable Story" (1895).

9 Another moment to which Machen attributes his "inoculation with the specific virus of literature" is reading Tennyson's poem "The Lotos-Eaters" (1832). He says that it was then "that I first delighted in poetry as poetry, for its own sake, apart from any story it might tell" (2013: 58-59).

10 The Mabinogion is a cycle of Welsh legends which includes stories about King Arthur and Merlin. Owain is one of the Knights of the Round Table.

11 Pan appears in similar circumstances in E. M. Forster's "The Story of a Panic" (1903) and Forrest Reid's "Pan's Pupil” (1905).

\section{References}

Bernheimer, Charles (2002) Decadent Subjects: The Idea of Decadents in Art, Literature, Philosophy, and Culture of the Fin de Siècle in Europe. Baltimore: Johns Hopkins University Press.

Boyiopoulos, Kostas (2010) “"Esoteric elements”: The Judeo-Christian scheme in Arthur Machen's The Great God Pan.' Neophilologus 94(2): 363-374.

Byron, Glennis (2012) 'Gothic in the 1890s.' In: Punter, David (ed.) A New Companion to the Gothic. Malden, MA: Wiley-Blackwell.

Dowling, Linda C. (2014) Language and Decadence in the Victorian Fin de Siecle. Princeton: Princeton University Press.

Ferguson, Christine (2002) 'Decadence as scientific fulfillment.' PMLA 117(3), 465-478.

Gawsworth, John (2013) The Life of Arthur Machen. Leyburn: Tartarus Press.

Joshi, S. T. (1990) The Weird Tale. Holicong, PA: Wildside Press.

Kaye, Richard A. (2007) 'Sexual identity at the fin de siècle.' In: Marshall, Gail (ed.) The Cambridge Companion to the Fin de Siècle. Cambridge: Cambridge University Press, 53-72.

Kristeva, Julia (1982) Powers of Horror: An Essay on Abjection. Columbia University Press.

Lovecraft, H. P. (2012) The Annotated Supernatural Horror in Literature. Edited by Sunand Tryambak Joshi. New York: Hippocampus Press.

Machen, Arthur (1923) Things Near and Far. London: Martin Secker.

Machen, Arthur (2006) The Great God Pan and The Hill of Dreams. Mineola, NY: Dover Publications.

Machen, Arthur (2011) The White People and Other Weird Stories. New York: Penguin Books.

Machen, Arthur (2013) Far Off Things. Miami: HardPress Publishing.

MacLeod, Kirsten (2006) Fictions of British Decadence: High Art, Popular Writing, and the Fin de Siècle. Basingstoke: Palgrave Macmillan.

Merivale, Patricia (1969) Pan the Goat-God: His Myth in Modern Times. Cambridge, Mass.: Harvard UP.

Nashe, Thomas (1905) The Works of Thomas Nashe. Edited by Ronald B. McKerrow, vol. 3. London: Bullen.

Navarette, Susan J. (1998) The Shape of Fear: Horror and the Fin de Siècle Culture of Decadence. Lexington, Ky.: The UP of Kentucky.

Ruddick, Nicholas (2007) 'The fantastic fiction of the fin de siècle.' In: Marshall, Gail (ed.) The Cambridge Companion to the Fin de Siècle. Cambridge: Cambridge University Press, 189206. 
Showalter, Elaine (1992) Sexual Anarchy: Gender and Culture at the Fin de Siècle. London: Virago. Thain, Marion (2007) 'Poetry.' In: Marshall, Gail (ed.) The Cambridge Companion to the Fin de Siècle. Cambridge: Cambridge University Press, 223-240.

Eva Valentová is currently doing her Ph.D. in the Literatures in English programme at the Faculty of Arts at Masaryk University in Brno, Czech Republic. She holds combined MA degrees in English Language and Literature, German Language and Literature, and in Teacher Training. Her research interests include fin de siècle, Decadence and the trickster figure. She wrote her MA thesis on Peter Pan as a trickster figure, and, in her Ph.D. project, she focuses on the role of the Greek god Pan in Decadent literature.

Address: Mgr. Eva Valentová, Department of English and American Studies, Faculty of Arts, Masaryk University, Arna Nováka 1, 60200 Brno, Czech Republic. [email: valentova.eva@gmail. com] 